\title{
PUBLIC'S SENTIMENT ANALYSIS ON SHOPEE-FOOD SERVICE USING LEXICON-BASED AND SUPPORT VECTOR MACHINE
}

\author{
Shafira Shalehanny ${ }^{1}$, Agung Triayudi ${ }^{2 *}$, Endah Tri Esti Handayani ${ }^{3}$ \\ Sistem Informasi, Fakultas Teknologi Komunikasi dan Informatika, Universitas Nasional \\ shafirashalehanny2018@student.unas.ac.id11), agungtriayudi@civitas.unas.ac.id ${ }^{2)}$, \\ endahtriesti@civitas.unas.ac.id ${ }^{3)}$ \\ $\left.{ }^{*}\right)$ Corresponding Author
}

\begin{abstract}
Abstrak
Bidang teknologi terus berkembang mengikuti perubahan zaman. Media sosial telah menjadi bagian tak terpisahkan dari kehidupan sehari-hari masyarakat dan menjadi wadah untuk menuliskan opini, mulai dari menuliskan ulasan atau tanggapan tentang suatu produk dan jasa yang digunakan. Menurut data yang didapat oleh Statista, di Indonesia sendiri pengguna Twitter mencapai angka 17.55 juta. Bagi para pelaku bisnis online, mengetahui nilai sentimen sangat penting agar dapat meningkatkan kinerja mereka. Dengan memanfaatkan teknologi seperti machine learning, NLP (Natural Processing Language), dan text mining dapat mengetahui maksud dari kalimat opini yang diberikan oleh suatu pengguna yang disebut analisis sentimen. Data diuji menggunakan gabungan dari dua metode yaitu Lexicon Based dan Support Vector Machine (SVM). Analisis data yang digunakan bersumber dari keyword Twitter dengan kata kunci 'ShopeeFood' dan 'syopifud'. Hasil analisa berupa nilai akurasi menggunakan kedua metode dengan nilai accuracy $87 \%$, precision $81 \%$, recall sebesar $75 \%$, dan f1-score sebesar $78 \%$.
\end{abstract}

Kata kunci: opini, Twitter, analisis sentimen, lexicon-based, support vector machine.

\begin{abstract}
Technology field following how era keep evolving. Social media already on everyone's daily life and being a place for writing their opinion, either review or response for product and service that already being used. Twitter are one of popular social media on Indonesia, according to Statista data it reach 17.55 million users. For online business sector, knowing sentiment score are really important to stepping up their business. The use of machine learning, NLP (Natural Processing Language), and text mining for knowing the real meaning of opinion words given by customer called sentiment analysis. Two methods are using for data testing, the first is Lexicon Based and the second is Support Vector Machine (SVM). Data source that used for sentiment analyst are from keyword 'ShopeeFood' and 'syopifud'. The result of analysis giving accuracy score 87\%, precision score $81 \%$, recall score $75 \%$, and f1-score $78 \%$.
\end{abstract}

Keyword: opinion, Twitter, sentiment analysis, lexicon-based, support vector machine.

\section{INTRODUCTION}

Improvement in any sector brings society awareness of service elements. These experiences show service quality with the result of various feedback (Pradopo \& Adhiansyah, 2019). Opinions or suggestions from people forming feedback, can be positive or negative (Rosdiana, Tungadi, Saharuna, \& Nur Yasir Utomo, 2019). Some of this feedback is just for knowing how others' opinions towards the service they're desired to use through social media (Pertiwi, Triayudi, \& Handayani, 2020). Twitter already being one of many social media that widely use by society, because users can freely be expressing opinions, feeling, activities, or other things (Salim \& Mayary, 2020). Twitter fast and effective organizations are capable to analyze society's perspective. One of it use for analyzing ECommerce such as Shopee (Triayudi, 2019).

A new feature was released by Shopee, called ShopeeFood. ShopeeFood serves food-drink delivery, teaming up with various industries (Vania \& Simbolon, 2021). Generally, the user will be commenting about the service that they already had. Therefore needed a way to analyze it, called sentiment analysis. Sentiment analysis is one of the Natural Processing Language (NLP) sectors, focusing on determining human traits on a topic or polarity score from a text (Jinju, Seyoung, \& Harrison, 2021). The research object of sentiment analysis is determining accuracy from a text 
(Jiménez-Zafra, Cruz-Díaz, Taboada, \& MartínValdivia, 2021).

On sentiment classifier there's two study focus: Machine Learning and Lexicon Based (Jiménez-Zafra et al., 2021). There's a dictionary on Lexicon Based to extract positive and negative words. Support Vector Machine (SVM) is suitable for knowing the accuracy and efficiency of high dimension features (Chazar \& Erawan, 2020; Marong, Raheem, Batcha, \& Mafas, 2020). Needed to be considered about sentiment effects on the result of value and accuracy level (Li, Li, Deng, Wang, \& Guo, 2021; Liu et al., 2021).

Previous related research about pilpres Indonesia campaign was conducted by Ahmad, Irsyad, Qandi, and Rakhmawati in 2019, purposing to comparing sentiment analysis methods. The accuracy result using Lexicon Based is 0.399, whereas for SVM is 0.839 (Najib, Irsyad, Qandi, \& Rakhmawati, 2019). Previous related research about Go-Pay users was conducted by Mahendrajaya, Buntoro, and Setyawan in 2019, purposing to classify sentiment class using Lexicon Based and knowing the results by two kernels using SVM. Results from this research got sentiment class for 923 positive classes and 287 negative classes using Lexicon method. SVM accuracy for the linear kernel on 1109 reviews is $89.17 \%$ on the other hand, the polynomial kernel on 1021 reviews is 84.38\% (Mahendrajaya, Buntoro, \& Setyawan, 2019). Previous related research about Indihome Twitter service was conducted by Tineges, Triayudi, and Sholihati in 2020, purposing to sentiment classifying, knowing accuracy result, and knowing how satisfied the service is given by Indihome using the SVM method. Result for accuracy is $87 \%$, $86 \%$ for precision, $95 \%$ for recall, $13 \%$ for error rate, and 90\% for f1-score (Tineges, Triayudi, \& Sholihati, 2020).

Previous related research about souvenir recommendations was conducted by Wilis, Hidayatulah, and Parasian in 2020, purposing to determining recommendations that have positive reviews from buyers. Accuracy, precision, and recall results using the SVM method are $86 \%, 93.20 \%$, and 91.11\%. Whereas Lexicon Based accuracy, precision, and recall is $88 \%, 97.56 \%$, and $88.89 \%$ (Wilis, Himawan, \& Silitonga, 2020).

Previous related research about East Java media sentiment analysis was conducted by Rustanto and Rakhmawati in 2020, purposing to compare Lexicon Based and SVM methods. Results using Lexicon Based method for accuracy is 58\%, the highest precision on neutral class is $72 \%$, and the highest recall on positive class is $75 \%$. Whereas using SVM the accuracy score is $44.7 \%$, the highest precision on positive class is $67.2 \%$, and the highest recall on positive class is $71.56 \%$ (Rustanto \& Rakhmawati, 2021).

As explained above, the formulation of the problem of this research is how getting analysis using Lexicon Based and SVM with tweet scope from 23rd October until 13th November 2021, mentioned 'ShopeeFood' and 'syopifud' in Indonesian. The purpose of this research for know the public's opinion about ShopeeFood service and know the accuracy score given by Lexicon Based and SVM methods.

\section{RESEARCH METHODS}

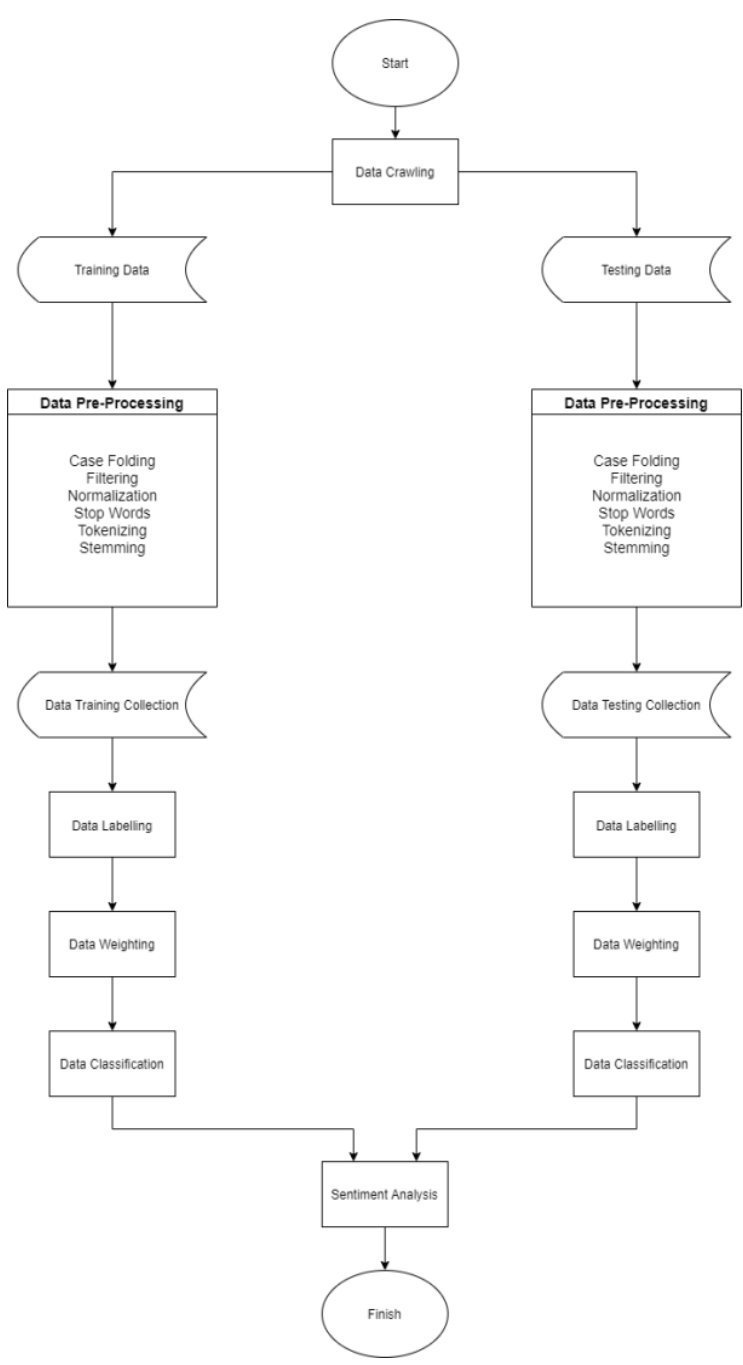

Figure 1. Sentiment Analysis Workflow

Figure 1 shows the workflow of sentiment analysis start from crawling, pre-processing, labeling, and classification.

\section{Crawling Data}




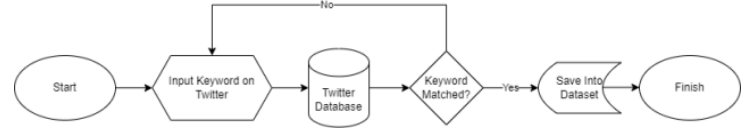

Figure 2. Crawling Data Step

Figure 2 shows how crawling step works, the data obtained from Twitter using Tweepy library and Python programming language. API Key is needed for authentication before starting crawling data. If the keyword already matched on user's desire, it will be saving on CSV (Comma Seperated Value) format.

\section{Pre-Processing Data}

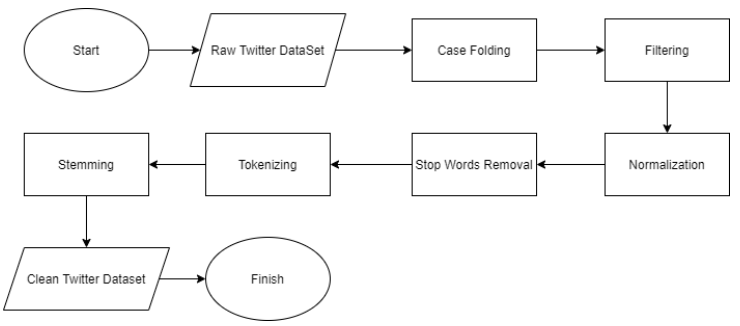

Figure 3. Pre-Processing Step

Retrieved data from crawling step still cannot be used and should pass pre-processing step. Because there are un-relevant, unmatched, and noisy data. As shown on Figure 3, step on preprocessing is case folding, filtering, normalization, stopwords, tokenizing and stemming.

\section{Labeling}

After raw data passes pre-processing, the next step is sentiment labeling. Labeling quality is depending on this process, because it can give high accuracy.

\section{Weighting using Lexicon Based}

Sentiment score already obtained, the next step is calculating every word that has sentiment score and calculating polarity score. Given score for positive is 2 , negative is 0 , and neutral is 1 .

\section{Classification using Support Vector Machine}

The concept of this classification is choosing which best hyperplane to divide two data classes with spesific values. One of the advantages is capable to work on high dimensions using kernel trick. SVM algorithm created by Hava Sielgemann and Vladimir Vapnik.

$$
h(x)=\sum_{p=1}^{m} \alpha_{p} s_{p} K\left(T_{i}, T_{j}\right)+b_{p q}
$$

\section{Description :}

$\alpha_{p} \quad$ : data input weight

$s_{p} \quad$ : data label on $\mathrm{p}$
$K\left(T_{i}, T_{j}\right):$ SVM kernel function

$b_{p q} \quad:$ bias parameter

\section{System Modelling}

The design of Unified Modeling Language or known as UML, is the form of dataflow from the sentiment analysis system Shopeefood service.

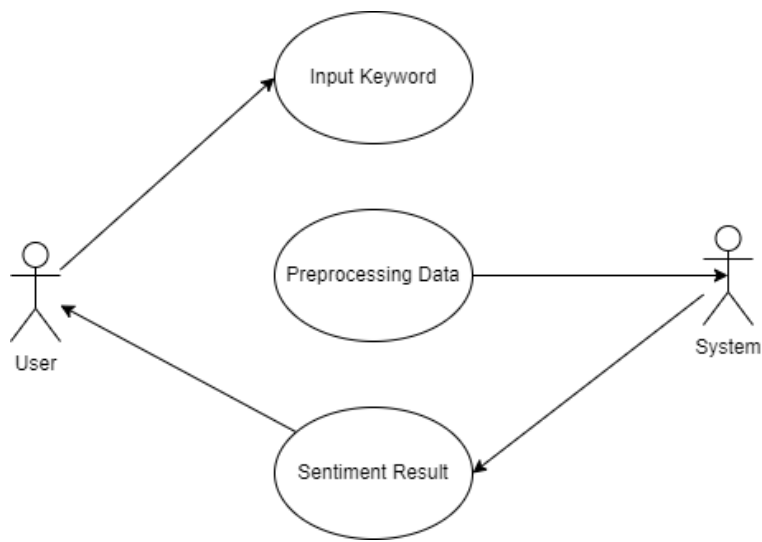

Figure 4. System Administration Use Case

Figure 4 shows use case of work on the system. Starting from inputting keywords by user on the system, it will immediately go into preprocessing step, till shows the sentiment result.

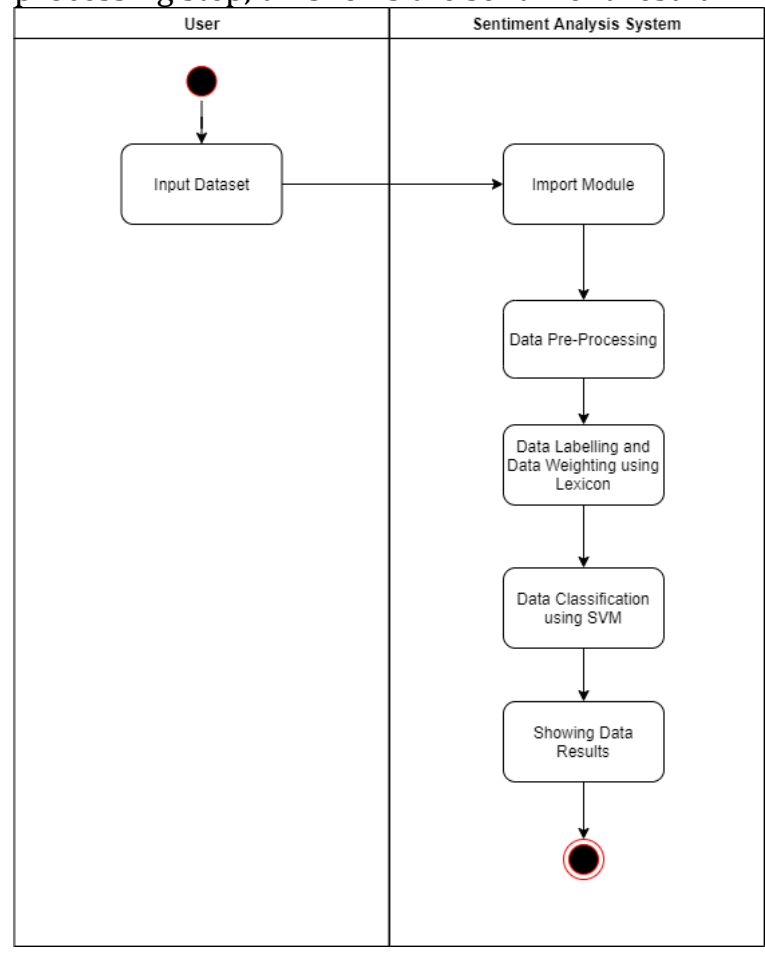

Figure 5. System Administration Activity Diagram

Activity diagram created on this application on Figure 5 starting from pre-processing until the result of data analysis. The keyword will be input and process till the data is ready enough to process 
sentiment analysis and show the result of the analysis.

\section{RESULTS AND DISCUSSION}

\section{Crawling Data}

Data retrieved starting from 23th October until 13th November 2021 taking the Twitter's tweets mentioned 'ShopeeFood' and 'syopifud'. Got 5508 tweets from crawling data. Using pandas for creating 'Created_At' and 'Tweets' data frame, and saving it as CSV format. Table 1 gives an example of the result of crawling dataset.

Table 1. Crawling Dataset

\begin{tabular}{cc}
\hline Created_At & Tweets \\
\hline 2021-10-23 01:28:34 & $\begin{array}{c}\text { @nnirwansyah Buka aja } \\
\text { google, "cara daftar } \\
\text { shopeefood driver" }\end{array}$ \\
\hline & $\begin{array}{c}\text { Wendy's promo khusus } \\
\text { gofood \&amp; shopeefood } \\
\text { 69k aja harin } \\
\text { 2021-10-22 06:20:51 } \\
\end{array}$ \\
& \\
\hline
\end{tabular}

\section{Pre-Processing Data}

Pre-processing data step using modules from Python include pandas, NLTK, and Sastrawi. The result of this process can be seen in Table 2 .

Table 2. Pre-Processing Step

\begin{tabular}{|c|c|c|}
\hline Step & Data Input & Data Output \\
\hline $\begin{array}{l}\text { Case } \\
\text { Folding } \\
\text { and } \\
\text { Filtering }\end{array}$ & $\begin{array}{l}\text { Wendy's promo } \\
\text { khusus gofood } \\
\text { \&amp; } \\
\text { shopeefood 69k } \\
\text { aja harin } \\
\text { https://t.co/skJcn } \\
\text { Aik3C }\end{array}$ & $\begin{array}{c}\text { wendys promo } \\
\text { khusus gofood } \\
\text { amp shopeefood } \\
\text { k aja harin }\end{array}$ \\
\hline $\begin{array}{l}\text { Stopwords } \\
\text { and } \\
\text { Normalizat } \\
\text { ion } \\
\end{array}$ & $\begin{array}{c}\text { wendys promo } \\
\text { khusus gofood } \\
\text { amp shopeefood } \mathrm{k} \\
\text { aja harin }\end{array}$ & $\begin{array}{c}\text { wendys promo } \\
\text { khusus gofood } \\
\text { shopeefood } \\
\text { harin }\end{array}$ \\
\hline $\begin{array}{l}\text { Tokenizing } \\
\text { and } \\
\text { Stemming }\end{array}$ & $\begin{array}{l}\text { wendys promo } \\
\text { khusus gofood } \\
\text { shopeefood harin }\end{array}$ & $\begin{array}{c}\text { ['wendys', } \\
\text { 'promo', } \\
\text { 'khusus', } \\
\text { 'gofood', } \\
\text { 'shopeefood', } \\
\text { 'harin'] }\end{array}$ \\
\hline
\end{tabular}

Data that has already been retrieved will firstly go into the case folding step, for spesific lower-casing all words. In the filtering step, there will be the removal of characters including: “@”, link, hashtag, whitespace, single character, numbers, and new line. After filtering there's normalization, to change slang words into standard words. The stopwords step for removing highfrequency words on NLTK's corpus, for example: karena, dan, lagi, jadi, and the others. Step for splitting sentences into words called tokenizing, the tokenized words will be changed into the basic expression with stemming.

\section{Lexicon Based Weighting}

After the data has already been cleaned up, the next step is weighting data according to the Indonesian dictionary or lexicon by evanmartua34 on Twitter COVID 19 analysis research. This lexicon is the combination from Inset by Fajri Koto, Sentiment Word by Agus Makmun, and Elang by abhimantramb.

Table 3. Word Weighting

\begin{tabular}{cccc}
\hline Dataset & $\begin{array}{c}\text { Weighted } \\
\text { Word }\end{array}$ & Polarity & Label \\
\hline $\begin{array}{c}\text { iya pakai } \\
\text { shopeefood } \\
\text { murah }\end{array}$ & 3 & 2 & Positive \\
\hline $\begin{array}{c}\text { pesan } \\
\text { shopeefood } \\
\text { kali batalkan } \\
\text { sistem alasan } \\
\text { driver susah } \\
\text { banget pesan } \\
\text { malem siang }\end{array}$ & -8 & 0 & Negative \\
\hline $\begin{array}{c}\text { driver } \\
\text { shopeefood }\end{array}$ & & & \\
penyelamatku \\
kelaparan
\end{tabular}

In Table 3 the given score for words on the lexicon is -5 until 5 , the summarization score will result on weighted words. The next step is giving polarity and labeling with conditions 2 for positive, 0 for negative, and 1 for neutral.

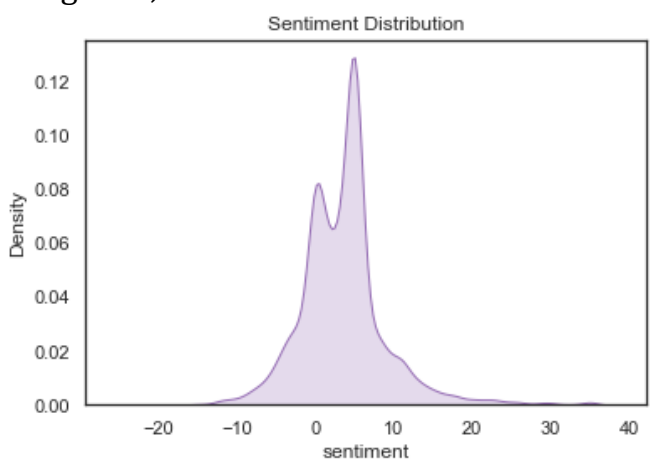

Figure 6. Sentiment Distribution Graphic

Figure 6 shows graphs for sentiment distribution on accumulated weighting words with the frequency weighting on every dataset sentences. Biggest distribution on 0-10 range.

\section{Support Vector Machine Classification}

This SVM classification uses TF-IDF for accumulating a word's weight. The output of the score is 2 for positive, 0 for negative, and 1 for 
neutral. Below is the example of the train data on Table 4.

T1 = selamat kota shopeefood

$\mathrm{T} 2$ = sulit cari driver shopeefood kah laper

$\mathrm{T} 3$ = shopeefood promonya kak

Table 4. Vectorized Sample on Training Data

\begin{tabular}{cccc} 
Data & T1 & T2 & T3 \\
\hline R1 & 0 & 0.43 & 0 \\
\hline R2 & 0 & 0.43 & 0 \\
\hline R3 & 0 & 0.43 & 0 \\
\hline R4 & 0 & 0 & 0.65 \\
\hline R5 & 0.65 & 0 & 0 \\
\hline R6 & 0 & 0.43 & 0 \\
\hline R7 & 0 & 0 & 0.65 \\
\hline R8 & 0.65 & 0 & 0 \\
\hline R9 & 0.39 & 0.26 & 0.39 \\
\hline R10 & 0 & 0.43 & 0 \\
\hline S & 2 & 0 & 1 \\
\hline
\end{tabular}

Training data classification using Sequential Training is early initiation for $\alpha($ alpha $)=0.5, \lambda$ $($ lambda $)=0.5, \gamma($ gamma $)=0.5, \quad \mathrm{C}=1$, dan $\varepsilon$ (epsilon) $=0.001$. With the use of linear kernel, will determining data on every rows and columns with comparing on each data as shown on Table 5.

Table 5. Kernel Function Compare on Training Data

\begin{tabular}{cccc}
\hline & T1 & T2 & T3 \\
\hline T1 & K (T1,T1) & K (T1,T2) & K (T1,T3) \\
\hline T2 & K (T2,T1) & K (T2,T2) & K (T2,T3) \\
\hline T3 & K (T3,T1) & K (T3,T2) & K (T3,T3) \\
\hline
\end{tabular}

Below is the formula for the linear kernel, the example using T1 and T2 data using equation (2).

$K\left(T_{i}, T_{j}\right)=T_{i} \times T_{j}$

$K(T 1, T 2)=((0 \times 0.43)+(0 \times 0.43)+(0 \times$ $0.43)+(0 \times 0)+(0.65 \times 0)+(0 \times 0.43)+(0 \times$

$0)+(0.65 \times 0)+(0.39 \times 0.26)+(0 \times 0.43))=$ 0.1014

Keep calculating kernel for the other data until matrix $3 \times 3$ is formed. The result for kernel function calculation is shown in Table 6.

Table 6. Kernel Function Result on Training Data

\begin{tabular}{cccc}
\hline & T1 & T2 & T3 \\
\hline T1 & 0.9971 & 0.1014 & 0.1521 \\
\hline T2 & 0.1014 & 0.9921 & 0.1014 \\
\hline T3 & 0.1521 & 0.1014 & 0.9971 \\
\hline
\end{tabular}

Searching Hessian Matrix score for example using T1 and T2 data on equation (3).

$D_{p q}=s_{p} s_{q}\left(K\left(\overrightarrow{T_{p}} \overrightarrow{T_{q}}\right)+\lambda^{2}\right.$

Description :

$D_{p q} \quad$ : matrix score on $\mathrm{pq}$

$s_{p} \quad:$ data label on $\mathrm{p}$

$s_{q} \quad:$ data label on $\mathrm{q}$

$\Lambda \quad$ : theoretical boundary derivative

For example on T1 and T2 data

$D_{p q}=(2)(0)\left((0.1014)+0.5^{2}\right)=0$

After Hessian Matrix has already been obtained, will calculate for error score using equation (4).

$E_{p}=\sum_{q=1}^{p} \alpha_{p} D_{p q}$

For example on T1 row.

$E_{T 1}=0.5 \times(4.9884+0+0.8042)=2.8963$

Searching for delta alpha score using equation (5).

$\delta \alpha_{p}=\min \left\{\max \left[\gamma\left(1-E_{p}\right),-\alpha_{p}\right], C-\alpha\right.$

For example on T1 row.

$\delta \alpha_{p}=(0.5(1-2.8963)=-0.94815$

The next step is calculating the new alpha score using equation (6).

$\boldsymbol{n e w} \alpha_{p}=\alpha_{p}+\delta \alpha_{p}$

For example on T1 row.

new $\alpha_{p}=0.5+(-0.94815)=-0.44815$

The dot product is divided by positive, negative, and neutral classes using equation (7).

$w=\sum_{p=1}^{n}$ new $\alpha_{p} y_{p} x_{p}$

$w_{\text {positive }}=(-0.44815 \times 2 \times 0.9971)+(0.75 \times 0 \times$ $0.1014)+(0.487175 \times 1 \times 0.1521)=$ $-0.8196014125$

$w_{\text {negative }}=(-0.44815 \times 2 \times 0.1014)+(0.75 \times$

$0 \times 0.9921)+(0.487175 \times 1 \times 0.1014)=$

$-0.041485275$

$w_{\text {neutral }}=(-0.44815 \times 2 \times 0.1521)+(0.75 \times 0 \times$

$0.1014)+(0.487175 \times 1 \times 0.9971)=$

0.3494349625

Dot product scores that have already been obtained before will be used for searching bias terms.

$b_{p q}=-\frac{1}{2}\left(w_{\text {pos }}+w_{\text {neg }}+w_{\text {net }}\right)=0.2558258625$

All the values already been obtained, now it's time to test on test data with given values as shown on Table 7.

$\mathrm{T} 1$ = cepat makan enak

Table 7. Vectorized Testing Data Sample

\begin{tabular}{cccccccccc}
\hline R1 & R2 & R3 & \multirow{2}{*}{ R4 } & R5 & R6 & R7 & R8 & $\begin{array}{c}\text { R } \\
9\end{array}$ & R10 \\
\hline 0 & 0.58 & 0 & 0.58 & 0 & 0 & 0.58 & 0 & 0 & 0 \\
\hline
\end{tabular}


Dot product calculating with train data and test data using equation (2). Result for dot product calculation shown in Table 8 .

$K(T 1, T 2)=(0 \times 0)+(0.58 \times 0)+(0 \times 0)+$ $(0.58 \times 0)+(0 \times 0.65)+(0 \times 0)+(0.58 \times 0)+$ $(0 \times 0.65)+(0 \times 0.39)+(0 \times 0)=0$

Table 8. Dot Product Score

\begin{tabular}{cc}
\hline T1 & 0 \\
\hline T2 & 0.2494 \\
\hline T3 & 0.754 \\
\hline
\end{tabular}

Last step on this classification is calculate the decision function on testing data using equation (1) with the decision score $h(x)=0$ (neutral, 1) or $\mathrm{h}(\mathrm{x})>0$ (positive, 2$)$ or $\mathrm{h}(\mathrm{x})<0$ (negative, 0$)$. $h(x)=((-0.44815 \times 2 \times 0)+0.2558258625)+$ $((0.75 \times 0 \times 0.2494)+0.2558258625)+$ $((0.487175 \times 1 \times 0.754)+0.2558258625=$ 1.1348075375

Conclusion for testing data $h(x)=$ 1.1348075375 is positive or 2 .

Table 9. Proportion Values on Training and Testing Data

\begin{tabular}{ccccc}
\hline Train:Test & Accuracy & Precision & Recall & $\begin{array}{c}\text { F1- } \\
\text { Score }\end{array}$ \\
\hline $50: 50$ & $83 \%$ & $78 \%$ & $66 \%$ & $70 \%$ \\
\hline $60: 40$ & $83 \%$ & $79 \%$ & $67 \%$ & $71 \%$ \\
\hline $70: 30$ & $85 \%$ & $80 \%$ & $70 \%$ & $74 \%$ \\
\hline $80: 20$ & $86 \%$ & $81 \%$ & $71 \%$ & $75 \%$ \\
\hline $90: 10$ & $87 \%$ & $81 \%$ & $75 \%$ & $78 \%$ \\
\hline
\end{tabular}

Determining which proportion values will give the best results, will be using classification report shown on Table 9. Giving attempt on training data and testing data, with proportion values 50:50, $60: 40,70: 30,80: 20$, and 90:10. The parameter is:

1. Accuracy, showing machine success rate on predicting the result.

$(T P+T N+T E) \div$ total $=(381+45+53) \div$ $551=0.869=87 \%$

2. Precision, machine representation on predicting true value.

$T E \div$ Neutral Prediction $=53 \div 72=$

0.7361111111111111

$T N \div$ Negative Prediction $=45 \div 58=$

0.7758620689655172

$T P \div$ Positive Prediction $=381 \div 421=$ 0.9049881235154394

Precision Total $=2.416961303592068 \div 3=$ $0.8056537678640226=81 \%$

3. Recall, showing system success rate on data prediction.

$T E \div(F N+F P+T E)=53 \div(6+19+53)=$ $53 \div 78=0.6794871794871795$
$T N \div(F E+F P+T N)=45 \div(6+21+45)=$ $45 \div 72=0.625$

$T P \div(F N+F E+T P)=381 \div(7+13+$

$381)=381 \div 401=0.9501246882793017$

Total Recall $=2.254611867766481 \div 3=$

$0.7515372892554937=75 \%$

4. F1-score, refering as avergae proportion from precision and recall.

$F 1-$ score $=2 \times$ Precision $\times$ Recall $\div$

$($ Precision + Recall $)=2 \times$

$0.8056537678640226 \times$

$0.7515372892554937 \div$

$(0.8056537678640226+$

$0.7515372892554937)=$

$0.777655183685699=78 \%$

Classification on positive, negative, and neutral sentiment from the true value and prediction value using confusion matrix. Got the score 381 for true positive, 53 for true neutral, and 45 for true negative as shown on Table 10.

Table 10. Confusion Matrix

\begin{tabular}{cccccc} 
& & \multicolumn{4}{c}{ Prediction Value } \\
\cline { 2 - 6 } & & $\begin{array}{c}\text { Negativ } \\
\text { e }\end{array}$ & $\begin{array}{c}\text { Neutra } \\
\text { l }\end{array}$ & Positive & Tot. \\
\hline \multirow{3}{*}{ True } & $\begin{array}{c}\text { Negativ } \\
\text { e }\end{array}$ & 45 & 6 & 21 & 72 \\
\cline { 2 - 6 } Value & Neutral & 6 & 53 & 19 & 78 \\
\cline { 2 - 6 } & Positive & 7 & 13 & 381 & 401 \\
\cline { 2 - 6 } & Total & 58 & 72 & 421 & 551 \\
\hline
\end{tabular}

\section{Application Implementation}

Application implementation for data testing as shown on Figure 7. Input keyword and amount of tweets that connected to Twitter API. After obtaining keyword and tweets, next step is crawling data, preprocessing, words weighting, and labeling.

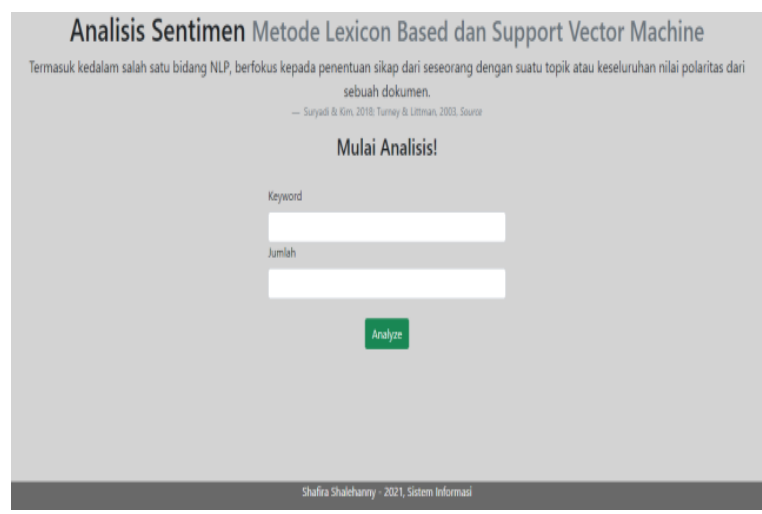

Figure 7. System Main Page

After click analyze button, will directing to result pages showing pie chart containing positive, negative, and neutral words. For this example using 1000 tweets, the result is $6.40 \%$ for positive, $4.40 \%$ for negative and $89.20 \%$ for neutral as shown on 
Figure 8. Analysis result depends on the keyword, language, and data amount.

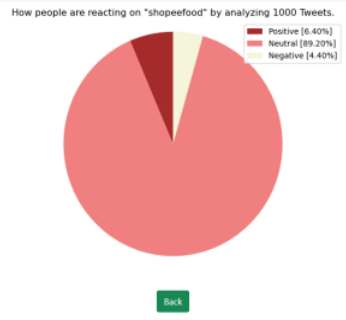

Figure 8. Analysis Result Page

\section{CONCLUSIONS AND SUGGESTIONS}

\section{Conclusions}

This research uses mixed methods (hybrid) for spesific, Lexicon Based dan Support Vector Machine (SVM) for knowing the public's opinion on Shopee-Food service. On the Lexicon method, the use of words is very important, therefore maximizing the result can be done by combining existing dictionaries. Labeling on a clean dataset is automatic, divided by three labels: positive, negative, and neutral. On SVM the accuracy score depends on every step. If the step didn't pass correctly or maximally, will giving an impact on getting high accuracy. But accuracy score isn't anything, because there are other parameters such as accuracy, precision, recall, and f1-score. From changing the proportion testing, the highest ratio result on proportion 90:10 with accuracy score $87 \%$, precision $81 \%$, recall score $75 \%$, and 11 -score $78 \%$. Testing data for knowing how it fits with the label using confusion matrix gives results 381 for true positive, 53 for true neutral, and 45 for true negative.

\section{Suggestions}

On the next research, using other media platforms can be considered to variating the dataset. The dataset should be added more for program learning, so it can increasing the accuracy of labeling.

\section{REFERENCES}

Chazar, C., \& Erawan, B. (2020). Machine Learning Diagnosis Kanker Payudara Menggunakan Algoritma Support Vector Machine. INFORMASI (Jurnal Informatika Dan Sistem Informasi), 12(1), 67-80. https://doi.org/10.37424/informasi.v12i1.4 8

Jiménez-Zafra, S. M., Cruz-Díaz, N. P., Taboada, M., \&
Martín-Valdivia, M. T. (2021). Negation detection for sentiment analysis: A case study in Spanish. Natural Language Engineering, 27(2), 225-248. https://doi.org/10.1017/S13513249200003 76

Jinju, K., Seyoung, P., \& Harrison, K. (2021). ANALYSIS OF CUSTOMER SENTIMENT ON PRODUCT FEATURES AFTER THE OUTBREAK OF CORONAVIRUS DISEASE (COVID-19) BASED ON ONLINE REVIEWS. Proceedings of the Design Society, 1(August), 457-466. https://doi.org/10.1017/pds.2021.46

Li, W., Li, X., Deng, J., Wang, Y., \& Guo, J. (2021). Sentiment based multi-index integrated scoring method to improve the accuracy of recommender system. Expert Systems with Applications, 179(March), 115105. https://doi.org/10.1016/j.eswa.2021.115105

Liu, C., Fang, F., Lin, X., Cai, T., Tan, X., Liu, J., \& Lu, X. (2021). Improving sentiment analysis accuracy with emoji embedding. Journal of Safety Science and Resilience, 2(4), 246-252. https://doi.org/10.1016/j.jnlssr.2021.10.003

Mahendrajaya, R., Buntoro, G. A., \& Setyawan, M. B. (2019). Analisis Sentimen Pengguna Gopay Menggunakan Metode Lexicon Based Dan Support Vector Machine. KOMPUTEK, 3(2), 52. https://doi.org/10.24269/jkt.v3i2.270

Marong, M., Raheem, M., Batcha, N. K., \& Mafas, R. (2020). Sentiment Analysis in E-Commerce: A Review on The Techniques and Algorithms Blockchain View project Sentiment Analysis View project Sentiment Analysis in ECommerce: A Review on The Techniques and Algorithms. Journal of Applied Technology and Innovation, 4(1), 6. Retrieved from https://www.researchgate.net/publication/3 39513566

Najib, A. C., Irsyad, A., Qandi, G. A., \& Rakhmawati, N. A. (2019). Perbandingan Metode Lexiconbased dan SVM untuk Analisis Sentimen Berbasis Ontologi pada Kampanye Pilpres Indonesia Tahun 2019 di Twitter. Fountain of Informatics Journal, 4(2), 41. https://doi.org/10.21111/fij.v4i2.3573

Pertiwi, A., Triayudi, A., \& Handayani, E. T. E. (2020). Sentiment Analysis of the Impact of Covid-19 on Indonesia's Economy through Social Media Using the ANN Method. Jurnal Mantik, 4(May), 605-612. Retrieved from https://iocscience.org/ejournal/index.php/m antik

Pradopo, L. R., \& Adhiansyah, R. M. (2019). Analis Strategi Kualitas Pelayanan untuk Peningkatan Rasa Kepuasan Konsumen pada PT Gojek (Studi Kasus Pelayanan Go Food). 
Journal of Information System, Applied, Management, Accounting and Research, 3(3), 27-32.

Rosdiana, Tungadi, E., Saharuna, Z., \& Nur Yasir Utomo, M. (2019). Analisis Sentimen pada Twitter terhadap Pelayanan Pemerintah Kota Makassar. Proceedings Seminar Nasional Teknik Elektro Dan Informatika, 87-93. Retrieved from https://dev.twitter.com

Rustanto, I., \& Rakhmawati, N. A. (2021). Media Sentiment Analysis of East Java Province: Lexicon-Based vs Machine Learning. IPTEK Journal of Proceedings Series, O(6), 203-208. Retrieved from https://iptek.its.ac.id/index.php/jps/article/ view/11094

Salim, S. S., \& Mayary, J. (2020). Analisis Sentimen Pengguna Twitter Terhadap Dompet Elektronik Dengan Metode Lexicon Based Dan K-Nearest Neighbor. Jurnal Ilmiah Informatika Komputer, 25(1), 1-17. https://doi.org/10.35760/ik.2020.v25i1.241 1

Tineges, R., Triayudi, A., \& Sholihati, I. D. (2020). Analisis Sentimen Terhadap Layanan Indihome Berdasarkan Twitter Dengan Metode Klasifikasi Support Vector Machine (SVM). JURNAL MEDIA INFORMATIKA BUDIDARMA, 4(3), 650. https://doi.org/10.30865/mib.v4i3.2181

Triayudi, A. (2019). Convolutional Neural Network For Test Classification On Twitter. Journal Software Engineering \& Intelligent Systems, 4(3), 123-131. Retrieved from www.jseis.org

Vania, I., \& Simbolon, R. (2021). Pengaruh Promo ShopeeFood Terhadap Minat Beli Pengguna Shopee (Di Daerah Tangerang Selatan). Jurnal Ekonomis, 14(2b), 46-58. Retrieved from https://jurnal.unai.edu/index.php/jeko/artic le/view/2593/1957

Wilis, K., Himawan, H., \& Silitonga, P. D. (2020). The Accuracy Comparison of Social Media Sentiment Analysis Using Lexicon Based and Support Vector Machine on Souvenir Recommendations. Test Engineering and Management, 82(3-4), 3953-3961. 